\title{
Mapping of Salinity Ingress Using Galdit Model for Sirkali Coastal Region: A Case Study
}

\author{
V. Satishkumar, S. Sankaran, Taufiquewarsi, B. Amarender, Ratnakar Dhakate \\ CSIR-National Geophysical Research Institute, Hyderabad, India \\ Email: satishkumar3113@gmail.com
}

Received 5 July 2016; accepted 21 August 2016; published 24 August 2016

Copyright (C) 2016 by authors and Scientific Research Publishing Inc.

This work is licensed under the Creative Commons Attribution International License (CC BY).

http://creativecommons.org/licenses/by/4.0/

(c) (i) Open Access

\section{Abstract}

A model is traced to evaluate and enumerate the significance of vulnerability to seawater intrusion due to excessive ground water withdrawals and some anthropogenic activities at coastal aquifers. So taking these issues into account few thematic maps which were influencing the saline water intrusion were prepared and overlaid using Geographical Information Systems (GIS). Based on GALDIT method, the groundwater vulnerability cartography has been assessed. To reckon the GALDIT index it requires six parameters like aquifer type, aquifer hydraulic conductivity, depth to groundwater level (AMSL), distance from the shore, impact of existing status of seawater intrusion and thickness of the aquifer. This GALDIT is the indicator scores and summing them and dividing by the total weight for determining the relative role of each one. Apart from this an identification of saltwater intruded area is done by using indicators of saltwater intrusion like $\mathrm{Cl} /\left(\mathrm{HCO}_{3}+\mathrm{CO}_{3}\right)$ ratio and $\mathrm{Na} / \mathrm{Cl}$ ratio. The vulnerability areas are classified as moderate with an area of $147.31 \mathrm{sq}$. $\mathrm{km}$ and low covering an area of $168.72 \mathrm{sq}$. $\mathrm{km}$ respectively based on the thematic maps. The final thematic map can be used for management of the coastal ground water resources.

\section{Keywords}

Saline Water Intrusion, GALDIT Index, Coastal Aquifer, Vulnerability Assessment, GIS

\section{Introduction}

During the last decades, the coastal aquifer systems are under to several pressures, due to urbanization and intensive agriculture. Approximately $70 \%$ of the population of the earth life is in coastal areas and the majority of these people depend on coastal aquifers for freshwater. The mis-management of water resources in an area 
causes negative effects including depletion of the aquifer storage, groundwater level decline, and seawater intrusion in coastal areas, land subsidence, quality deterioration and environmental problems in other water bodies. As this coastal aquifers constitute an important source of fresh water supply but are often confronted with the problem of seawater intrusion. In coastal plains, due to inadequate storage facilities, most of the rainwater flows towards sea as runoff. Population growth, agricultural, industrial and domestic requirements exploit the available ground water with decreasing recharge areas. Regulation of ground water extraction is essential to optimize the overdraft, reducing the risk of seawater intrusion. The entire seawater intrusion phenomenon is governed by Ghyben-Herzberg relation [1]. The lighter fresh water lies over the seawater and the boundary surface between them is known as the freshwater-seawater interface. This distribution was attributed to a hydrostatic equilibrium existing between the two fluids of different densities. For each meter of fresh ground water found above sea level, $40 \mathrm{~m}$ of freshwater exists below sea level at that point. When drawdown occurs, the base of the freshwater lens is adjusted at a rate of $40 \mathrm{~m}$ for each meter of drawdown in the well through upcoming effect.

Rainfall plays a major role in recharge of an oceanic island. When this precipitation is sufficient it gives a sufficient need of fresh water and this freshwater exists as a lens above seawater due to the variation in there densities. Freshwater lenses have been described as some of the most vulnerable aquifer systems in the world, with seawater intrusion (SWI) (i.e., the encroachment of seawater into fresh coastal aquifers) being a critical management issue [2]. This interface layer is weaken by various factors like low topography of oceanic island, less freshwater availability and heavy pumping, heavy reliance by local communities with few alternative water supplies [3] and [2].

Generally, the term of vulnerability refers to the potential degree of harm that can be expected depending on the characteristics of an element at risk with respect to a certain hazard [4] [5]. Relating to groundwater, the vulnerability is defined by [6] as "the sensitivity of groundwater quality to an imposed contaminant load, which is determined by the intrinsic characteristics of the aquifer". Thus the vulnerability of groundwater to different pollutants or to seawater intrusion constitutes a subject of analysis in several studies [7]-[9]. Also the vulnerability of soil to salinization is demonstrated in many studies [10]-[14].

In this study an attempt is made to outline the area of scope of saline water intrusion by preparation of vulnerability map in the Sirkali coastal region. This study will be helpful for the groundwater management and plans to preserve the freshwater.

\section{Study Area}

The study area lies between longitudes: $79^{\circ} 05^{\prime} 00^{\prime \prime}$ to $11^{\circ} 15^{\prime} 30^{\prime \prime} \mathrm{N}$ with an area of 316.2 sq. km (Figure 1 ). Sirkazhi is located in the Uppanar river basin with an area of $168.8 \mathrm{sq}$. km and Mannampandal in Cauvery river basin with an area of $147.4 \mathrm{sq}$. km. Topographically the area is flat, except beach ridges tending towards the Bay of Bengal. The elevation of the Uppanar River Basin which is the upper part of the study area varies from 0 to $14.33 \mathrm{~m}$ above mean sea level (amsl) and in low areas was <3 m (amsl). In Uppanar river basin backwater, proceed to a distance of above $20 \mathrm{~km}$ towards inland. In Cauvery river basin which is the lower part of the study area the relief varies from 0.0 to $17.3 \mathrm{~m}$ (amsl) and the backwater inundation is within $5 \mathrm{~km}$ from the coast where the topography is around $<3 \mathrm{~m}$ amsl. The annual average rainfall ranges from $1200-1500 \mathrm{~mm} / \mathrm{yr}$ with a major contribution from NE monsoon during October-December. Economically this area depends on agriculture, prawn cultivation and brick industries.

Geologically the area known as younger (quaternary) deposits [15]; the sediments classified as alluvial plain deposits (Cauvery formation) of the Cauvery River and its distributaries, fluviomarine deltaic plain deposits (Nagapattinam formation), marine coastal plain deposits (East Coast formation). Paleo-channels noticed with admixtures of sand, silt clay and gravels. The deltaic plain includes paleo tidal flats with clays and sand, sand ridges of grey brown sand. The marine coastal plains include tidal flats, deposits of sand, clay and tidal clays. The study area underlined by sedimentary formations and geomorphologically it is divided into the three major units (i.e., fluvial, fluviomarine, and marine units). Groundwater occurs under unconfined, semi-confined, and represented by sands, gravels, sandy clays and variegated clays, and its thickness ranges from 10 - 35 m [16]. Groundwater extracted through the shallow tube wells and dug-cum-bore wells. In the coastal area, fresh water is available only in beach ridges and in sand dunes.

\section{Methodology}

In this study we carry out the application of the GALDIT method to aquifer of Sirkali coastal region. This 


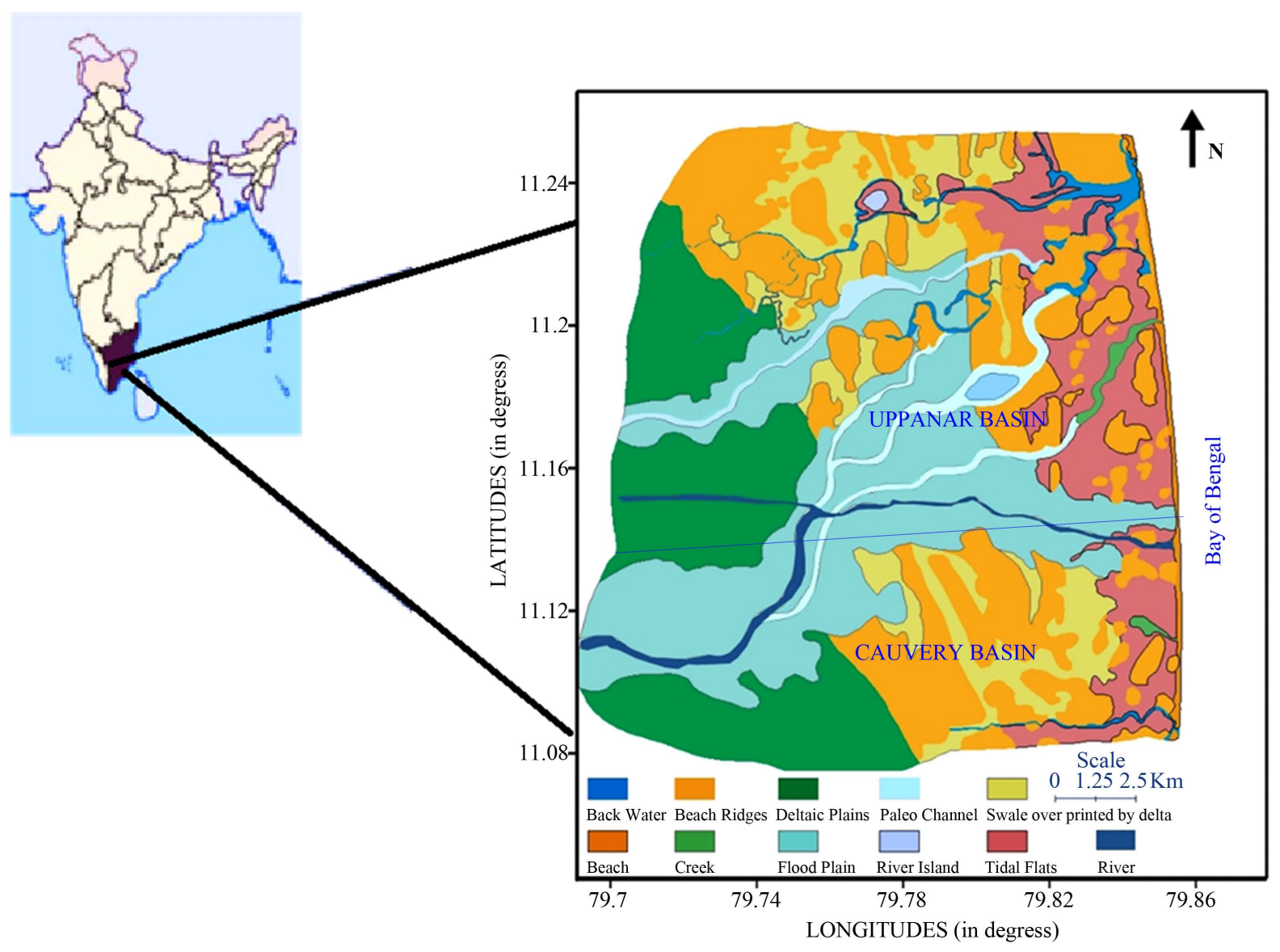

Figure 1. Key map of the study area showing different geomorphological units.

method acts to distinguish the vulnerability of the coastal aquifers, based on six parameters existing (Table 1). The parameters of the intrusion of sea water were described by [17].

A numerical grade system has been framed using the parameters to assess saline water intrusion extent. The system contains three significant parts: weights, ranges and ratings. Each parameter has been assessed with respect to the other parameter to determine the relation of each factor by assigning a relative weight. The other parameter using GALDIT method indicates an identification of saltwater intruded area using the ration like $\mathrm{Cl} /\left(\mathrm{HCO}_{3}+\mathrm{CO}_{3}\right)$. Parameters that are normally used for seawater intrusion analysis are Ca/Mg, Total alkalinity/ Total hardness, $\mathrm{Cl} /\left(\mathrm{CO}_{3}+\mathrm{HCO}_{3}\right)$ ratios, Chloride content, Electrical conductivity (EC) etc. In this study, the $\mathrm{Cl} /\left(\mathrm{CO}_{3}+\mathrm{HCO}_{3}\right)$ ratio is used to delineate the interface (Table 2). Chloride is most dominant in ocean water and normally occurs in small amounts in ground water, while $\mathrm{HCO}_{3}$ is usually the most abundant negative ion in ground water but it occurs in minor amounts in the seawater. The $\mathrm{Cl} /\left(\mathrm{CO}_{3}+\mathrm{HCO}_{3}\right)$ ratio is calculated for all the wells and these point values are taken to prepare the spatial variation map using the kriging and IDW interpolation technique. Similarly, the other factors are evaluated and used. From these, the GALDIT (Combining the first letters of the above significant factors) Index is calculated as:

$$
\text { GALDIT Index }=\left(W_{1} \times G\right)+\left(W_{2} \times A\right)+\left(W_{3} \times L\right)+\left(W_{4} \times D\right)+\left(W_{5} \times I\right)+\left(W_{6} \times T\right)
$$

where, $W_{1}$ to $W_{6}$ are the relative weights assigned to the six factors. The ratings of for all the factors were assigned by reclassifying the influencing factors with different ranges through a trial and error method. In this study, the ranges and weight ages were modified to suit to the study area [18] [19].

\subsection{Mapping of GALDIT Index}

Mapping of GALDIT index gives its variation in the study area, which is done by Arc GIS 10.3 software. For 
Table 1. Parameters of GALDIT.

\begin{tabular}{cccccc} 
Parameters & Weight & Very low & Low & Medium & High \\
\hline $\boldsymbol{G}$ : Groundwater occurrence (aquifer type) & 1 & $\begin{array}{c}\text { Bounded } \\
\text { aquifer }\end{array}$ & $\begin{array}{c}\text { Leaky } \\
\text { confined }\end{array}$ & Unconfined & Confined \\
A: Aquifer hydraulic conductivity (m/day) & 3 & $<5$ & $5-10$ & $10-40$ & $>40$ \\
$\boldsymbol{L}$ : Height of groundwater level above sea level (m) & 4 & $>2$ & $1.5-2$ & $1-1.5$ & $<1$ \\
$\boldsymbol{D}:$ Distance from the shore (m) & 4 & $>1000$ & $1000-750$ & $750-500$ & $<500$ \\
$\boldsymbol{I}:$ Impact of existing status of sea water intrusion & 1 & $<1$ & $1-1.5$ & $1.5-2$ & $>2$ \\
$\boldsymbol{T}$ : Thickness of aquifer being mapped (m) & 2 & $<5$ & $5-7.5$ & $7.5-10$ & $>10$ \\
\hline
\end{tabular}

Table 2. Impact of existing status of seawater intrusion.

\begin{tabular}{|c|c|c|c|c|c|c|c|c|c|c|}
\hline $\mathbf{X}$ & $\mathbf{Y}$ & W. NO & $\begin{array}{c}\text { E.C. } \\
\text { (uS/cm) }\end{array}$ & $\begin{array}{c}\text { TDS } \\
(\mathrm{mg} / \mathrm{l})\end{array}$ & $\begin{array}{c}\text { T. Alk as } \\
\mathrm{CaCO}_{3}(\mathrm{mg} / \mathrm{l})\end{array}$ & $\begin{array}{c}\text { T. Hard as } \\
\mathrm{CaCO}_{3}(\mathrm{mg} / \mathrm{l})\end{array}$ & $\begin{array}{c}\mathrm{Cl}^{-} \\
(\mathrm{mg} / \mathrm{l})\end{array}$ & $\mathrm{HCO}_{3}$ & $\mathrm{CO}_{3}$ & $\mathrm{Cl} / \mathrm{HCO}_{3}+\mathrm{CO}_{3}$ \\
\hline 79.7377 & 11.2359 & S1 & 1295 & 829 & 340 & 200 & 274 & 340 & 204 & 0.503676471 \\
\hline 79.7186 & 11.2299 & S2 & 2390 & 1530 & 360 & 412 & 295 & 360 & 216 & 0.512152778 \\
\hline 79.7042 & 11.1641 & S4 & 1338 & 856 & 510 & 80 & 380 & 510 & 306 & 0.465539216 \\
\hline 79.7136 & 11.1460 & S5 & 358 & 229 & 320 & 148 & 270 & 320 & 192 & 0.527167969 \\
\hline 79.7612 & 11.1653 & S6 & 1115 & 714 & 440 & 200 & 320 & 440 & 264 & 0.454403409 \\
\hline 79.7628 & 11.2071 & S8 & 1384 & 886 & 400 & 200 & 480 & 400 & 240 & 0.75 \\
\hline 79.7374 & 11.2209 & S9 & 4400 & 2816 & 260 & 548 & 1280 & 260 & 156 & 3.076923077 \\
\hline 79.7996 & 11.2261 & $\mathrm{~S} 10$ & 1754 & 1123 & 540 & 320 & 350 & 540 & 324 & 0.405092593 \\
\hline 79.7510 & 11.2311 & S11 & 1050 & 672 & 280 & 280 & 250 & 280 & 168 & 0.557857143 \\
\hline 79.7776 & 11.2500 & $\mathrm{~S} 12$ & 2410 & 1542 & 260 & 440 & 760 & 260 & 156 & 1.826923077 \\
\hline 79.7816 & 11.2089 & $\mathrm{~S} 13$ & 1085 & 694 & 240 & 220 & 340 & 240 & 144 & 0.885130208 \\
\hline 79.8048 & 11.1886 & S15 & 1190 & 762 & 300 & 220 & 220 & 300 & 180 & 0.4583333333 \\
\hline 79.7976 & 11.1522 & S17 & 1191 & 762 & 410 & 148 & 460 & 410 & 246 & 0.700990854 \\
\hline 79.8446 & 11.1678 & $\mathrm{~S} 18$ & 2690 & 1722 & 380 & 280 & 840 & 380 & 228 & 1.381578947 \\
\hline 79.8486 & 11.1905 & S19 & 4300 & 2752 & 680 & 348 & 1321 & 680 & 408 & 1.214356618 \\
\hline 79.8395 & 11.2022 & S20 & 5830 & 3731 & 160 & 560 & 3260 & 160 & 96 & 12.734375 \\
\hline 79.8283 & 11.2122 & S21 & 3190 & 2042 & 500 & 440 & 1670 & 500 & 300 & 2.0875 \\
\hline 79.7847 & 11.1014 & S22 & 772 & 494 & 300 & 180 & 170 & 300 & 180 & 0.354041667 \\
\hline 79.7534 & 11.1073 & S24 & 800 & 512 & 260 & 136 & 200 & 260 & 156 & 0.480769231 \\
\hline 79.7341 & 11.0782 & S25 & 789 & 505 & 280 & 160 & 120 & 280 & 168 & 0.267857143 \\
\hline 79.7177 & 11.1150 & S27 & 1180 & 755 & 320 & 210 & 310 & 320 & 192 & 0.60546875 \\
\hline 79.7340 & 11.1523 & S30 & 694 & 444 & 240 & 190 & 240 & 240 & 144 & 0.625 \\
\hline 79.7578 & 11.1308 & S31 & 550 & 352 & 220 & 120 & 200 & 220 & 132 & 0.568181818 \\
\hline 79.7904 & 11.1325 & S32 & 560 & 358 & 260 & 100 & 160 & 260 & 156 & 0.384615385 \\
\hline 79.8115 & 11.1132 & S36 & 787 & 504 & 340 & 128 & 200 & 340 & 204 & 0.367647059 \\
\hline 79.8293 & 11.0922 & S37 & 1454 & 931 & 390 & 376 & 650 & 390 & 234 & 1.0416666667 \\
\hline 79.8534 & 11.0941 & S38 & 1713 & 1096 & 380 & 280 & 460 & 380 & 228 & 0.756578947 \\
\hline 79.8366 & 11.1138 & S39 & 2030 & 1299 & 260 & 480 & 906 & 260 & 156 & 2.177884615 \\
\hline 79.8503 & 11.1443 & S40 & 1548 & 991 & 380 & 48 & 530 & 380 & 228 & 0.871710526 \\
\hline 79.8414 & 11.1553 & S41 & 2160 & 1382 & 520 & 196 & 690 & 520 & 312 & 0.829326923 \\
\hline 79.8495 & 11.1313 & S42 & 2260 & 1446 & 500 & 300 & 640 & 500 & 300 & 0.8 \\
\hline 79.8395 & 11.2413 & S43 & 1154 & 739 & 300 & 260 & 410 & 300 & 180 & 0.854166667 \\
\hline 79.8109 & 11.2515 & S45 & 1042 & 667 & 320 & 184 & 350 & 320 & 192 & 0.68359375 \\
\hline 79.7637 & 11.0769 & S64 & 611 & 391 & 280 & 210 & 120 & 280 & 168 & 0.267857143 \\
\hline
\end{tabular}


mapping of this GALDIT index it requires the location of all samplimg sites and there parameters data. The important steps involved for mappings are georeferencing, digitization and spatial interpolation. Georeferencing defines the location of a dataset using known map coordinates and assigns it a coordinate system. This allows for the dataset to be viewed, queried, and analyzed with other geographic data. Digitzing is the process of making features which can be editable and these features have an additional spatial and non-spatial attributes that can be assigned. By digitizing these features, you make them available for mapping once you have added the tabular data to the attribute table. Spatial interpretation is the process of using points with known values to estimate values at other points. Spatial interpretation is therefore a means of creating surface data from sample points so that the surface data can be used for analysis.

\subsection{Results and Discussion}

\subsubsection{Groundwater Occurrence, $G$}

The parameter $G$ (aquifer type) affects the degree of advancement of the marine water into the groundwater. From the pump test data and TDS contours it is evident that the aquifer is leaky and unconfined in nature with rich groundwater potential and hence a rating of 5.5 to 7.5 is adopted as per the specifications. Also, from the field observations it is evident that the aquifer is shallow and confined in nature. An unconfined aquifer, in natural conditions, is more affected by marine water intrusion than a confined one. In the study area, the aquifer is unconfined and corresponds to class 7.5 as in Figure 2.

\subsubsection{Aquifer Hydraulic Conductivity, $A$}

Hydraulic conductivity or the permeability is the aptitude of a soil or rock to let itself cross by water under the effect of a hydraulic gradient. A layer of containment is a geological unit of low or very low hydraulic conductivity ( $<$ to $10^{-7} \mathrm{~m} / \mathrm{s}$ ) whereas the formations considered as aquifers. It consists of materials whose hydraulic conductivity exceeds $10^{-4} \mathrm{~m} / \mathrm{s}$. Finally from all the studies conducted to evaluate the hydraulic conductivity in the study area, we can conclude that the hydraulic conductivity varies up to $5 \mathrm{~m} / \mathrm{sec}$ and hence a common GALDIT rating of 2.5 can be assigned for the entire study area and as in Figure 3.

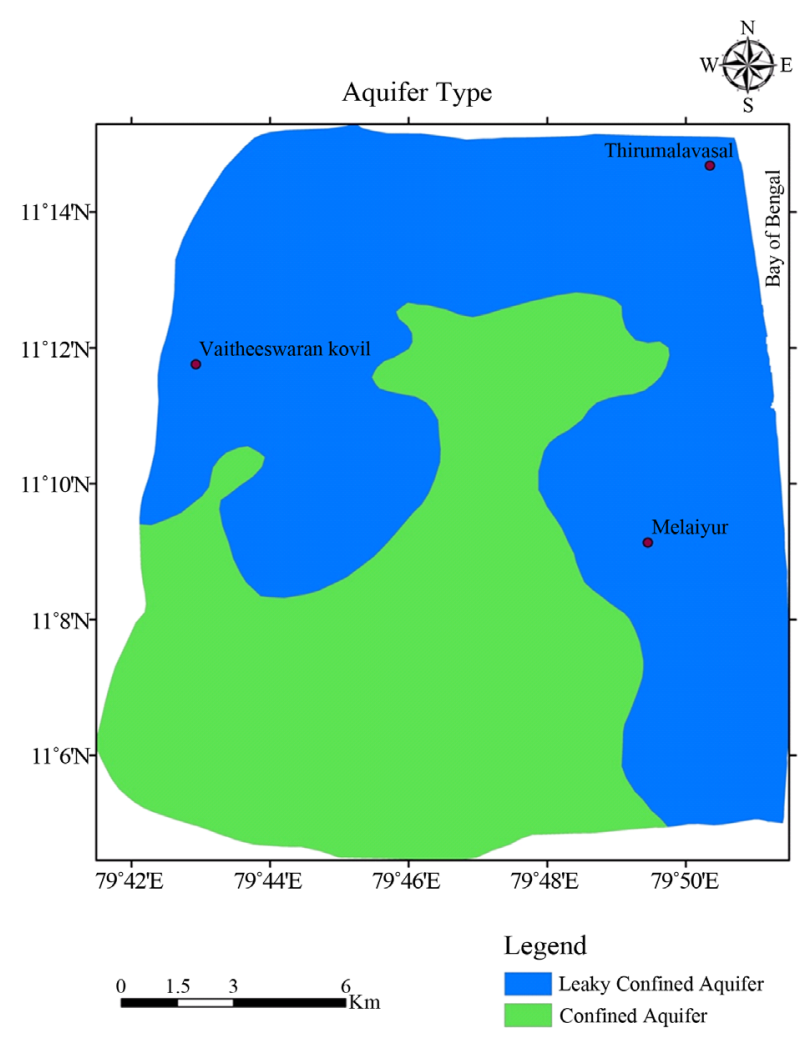

Figure 2. Parameter $G$ (aquifer type). 


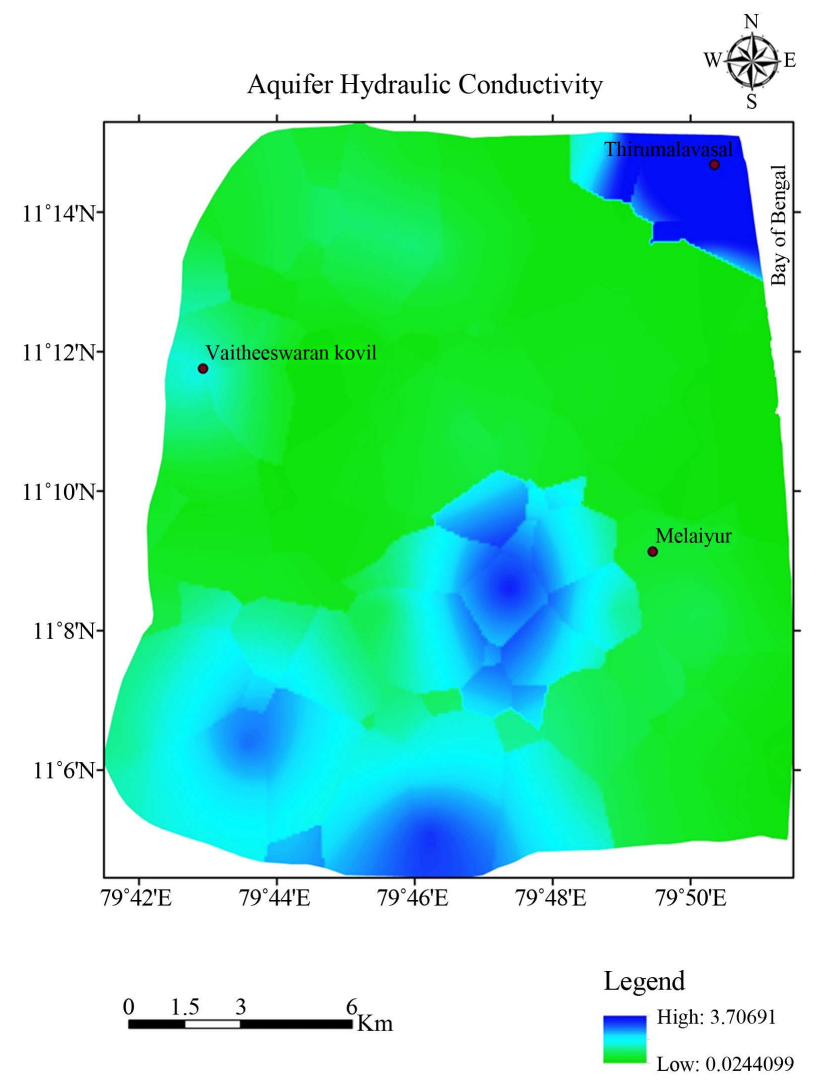

Figure 3. Parameter $A$ (aquifer hydraulic conductivity).

\subsubsection{Height of Water above the Sea Level, $L$}

The level of groundwater compared to the average altitude of the sea is a very significant factor in the evaluation of the sea water intrusion in any area. By this it determines the possibility of the water pressure to move back the sea front [7]. In general the minimal values of groundwater level below the sea level remain most significant, because they provide the strongest possible vulnerability to this marine water intrusion. The groundwater levels were measured at the monitoring wells identified. The parameter required for the present study, " $L$ " is obtained by reducing the water level with respect to mean sea level and is shown in Figure 4.

\subsubsection{Distance from the Shore, $D$}

The impact of the intrusion of sea water generally decreases when moving perpendicularly to the shore towards the interior. This parameter was estimated according to three distances (500 m, $750 \mathrm{~m}$ and $1000 \mathrm{~m}$ ) perpendicular to the line of coast and the rivers of the uppanar and cauvery River. The maximum estimate of 10 is adopted for the distance lower than $500 \mathrm{~m}$ of the coast, whereas the minimal one (2.5) is allotted for all those higher than $1000 \mathrm{~m}$. The values of 7.5 and 5 are given, respectively, with the distances from 500 to $750 \mathrm{~m}$ and from 750 to $1000 \mathrm{~m}$. The distribution of the parameter D of GALDIT of the aquifer of coast is represented in Figure 5.

\subsubsection{Impact of Existing Status of Saltwater Intrusion, $I$}

The chloride concentration of groundwater defines the extent of saltwater intrusion. The chloride concentration in the range of 120 to $3260 \mathrm{mg} / \mathrm{l}$ is indicative of saltwater intrusion [20]. The present results infer that the aquifer water is contaminated with saltwater as $\mathrm{Cl}^{-}$, the most abundant ion in saltwater, is in higher proportions. The $\mathrm{HCO}_{3}^{-}$ion which is the most dominant ion in fresh groundwater occurs generally in small amounts in saltwater. Chloride concentration greater than $250 \mathrm{mg} / \mathrm{l}$ is considered unfit for drinking purpose. The existing imbalance in the seawater-freshwater interface should be considered while mapping the aquifer vulnerability to seawater intrusion [21]. Chloride is the dominant ion in the seawater and it is only available in small quantities in groundwater while bicarbonate, which is available in large quantities in groundwater, occurs only in very small quantities in 


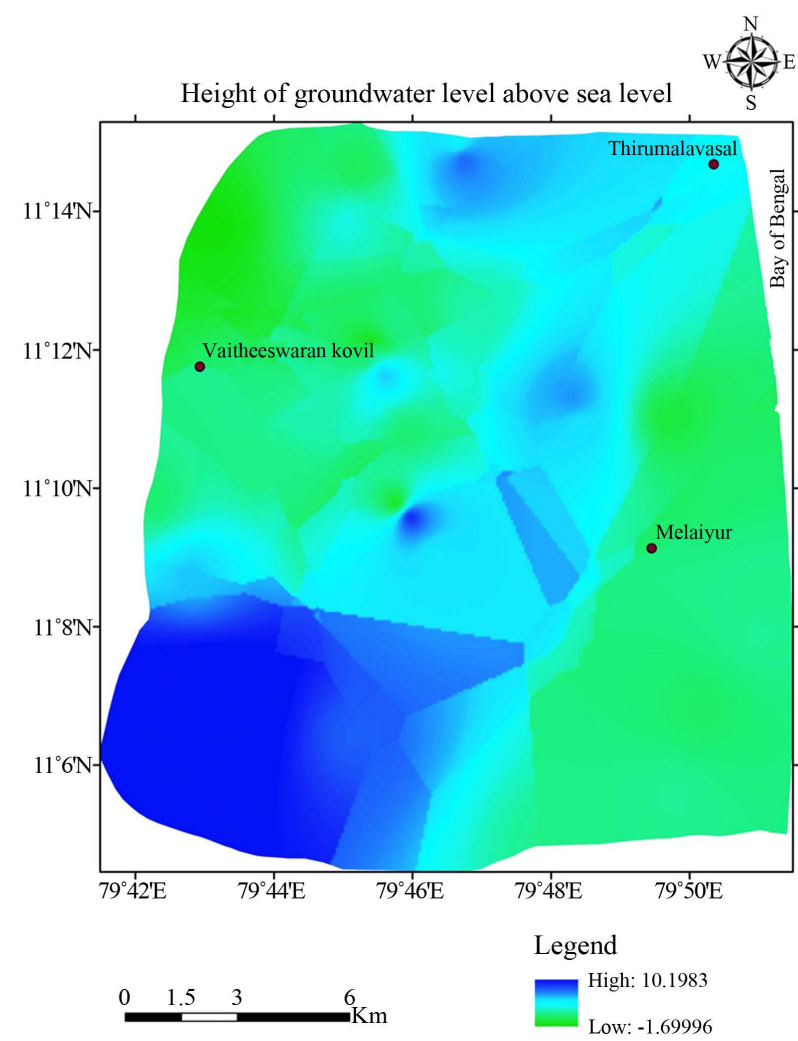

Figure 4. Parameter $L$ (height of water above the sea level).

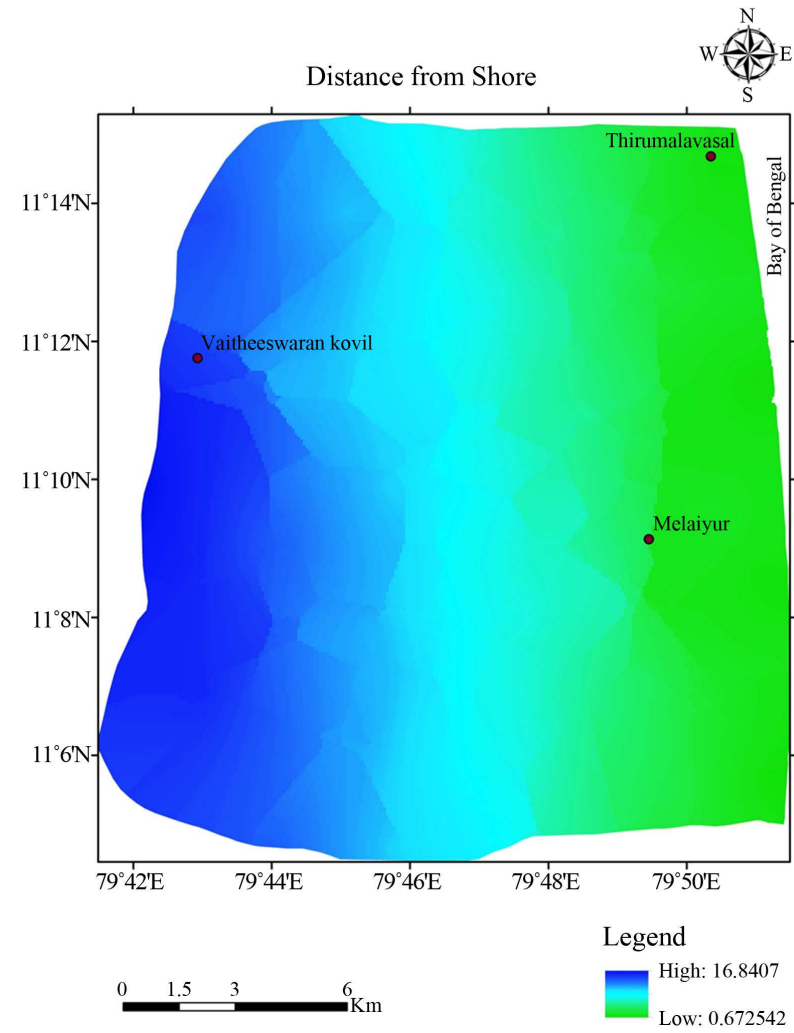

Figure 5. Parameter $D$ (distance from the shore). 
seawater. The ratio $\mathrm{Cl}^{-} /\left[\mathrm{HCO}_{3}^{-}+\mathrm{CO}_{3}^{-}\right]$is a criterion to identify the extent of seawater intrusion into the coastal aquifers [22] and can be used if the chemical analysis data is available. The evaluation of this parameter was given starting from an ionic analysis of chromatography at the laboratory of the Centre for Water Resources Development and Management (CWRDM) Calicut, Kerala. The distribution of this parameter GALDIT is presented in Figure 6(a).

\subsubsection{Thickness of the Aquifer, $Z$}

The thickness of the aquifer is obtained from the electrical resistivity survey conducted in the study area at 39 locations Figure 6(b). The resistivity survey indicated that the area consists of shallow unconfined aquifer with the thickness ranging from $2.6 \mathrm{~m}$ to $75.2 \mathrm{~m}$. From the resistivity survey we can observe that all the values are ranging from $2.6 \mathrm{~m}$ to $75.2 \mathrm{~m}$ and hence the GALDIT rating of 2.5 to 10 is adopted in the study area as shown in Figure 7.

\subsection{Computing the GALDIT Index}

The calculation of GALDIT Index and the superposition of the various layers of the parameters in a Geographical Information System (GIS) make it possible to identify the significant and susceptible areas that could be affected by a seawater intrusion. The map derived for this study area is shown in Figure 8. The figure clearly states that the area closer to the coast is in moderate vulnerable and away from the coast its under low vulnerable state and in the upper part of the study area it is observed that NNW part is in the moderate vulnerable condition that is due to the surface phenomena like aquaculture and the backwaters as seen in the Figure 1. This moderate vulnerability class is very well matched with the TDS of groundwater in the study area Figure 9.

\section{Conclusions}

Geologically the area known as younger (quaternary) deposits; the sediments classified as alluvial plain deposits

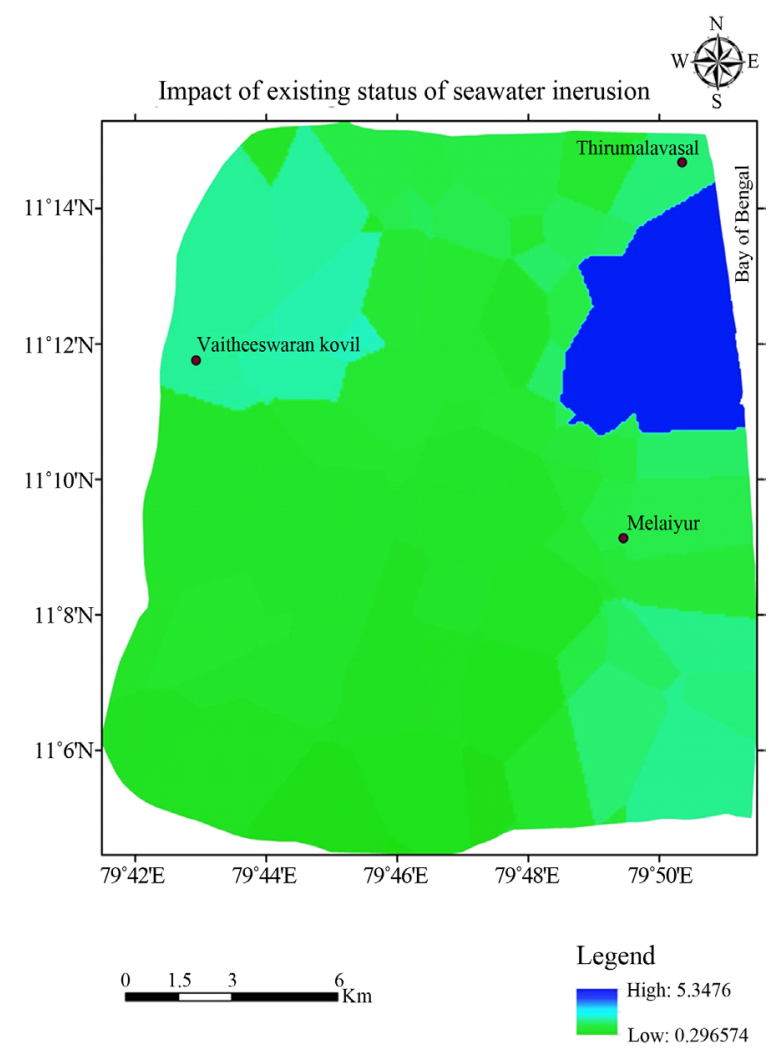

(a)

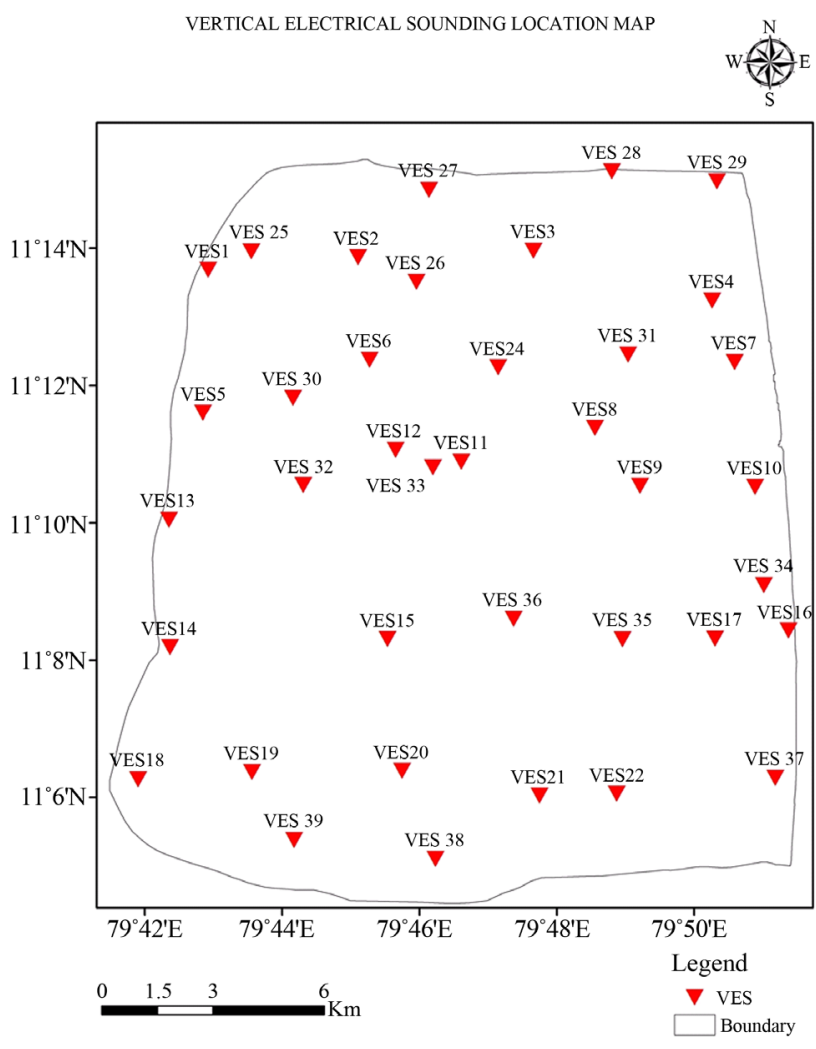

(b)

Figure 6. (a) Parameter I (impact of existing status of saltwater intrusion); (b) Vertical electrical sounding location map. 


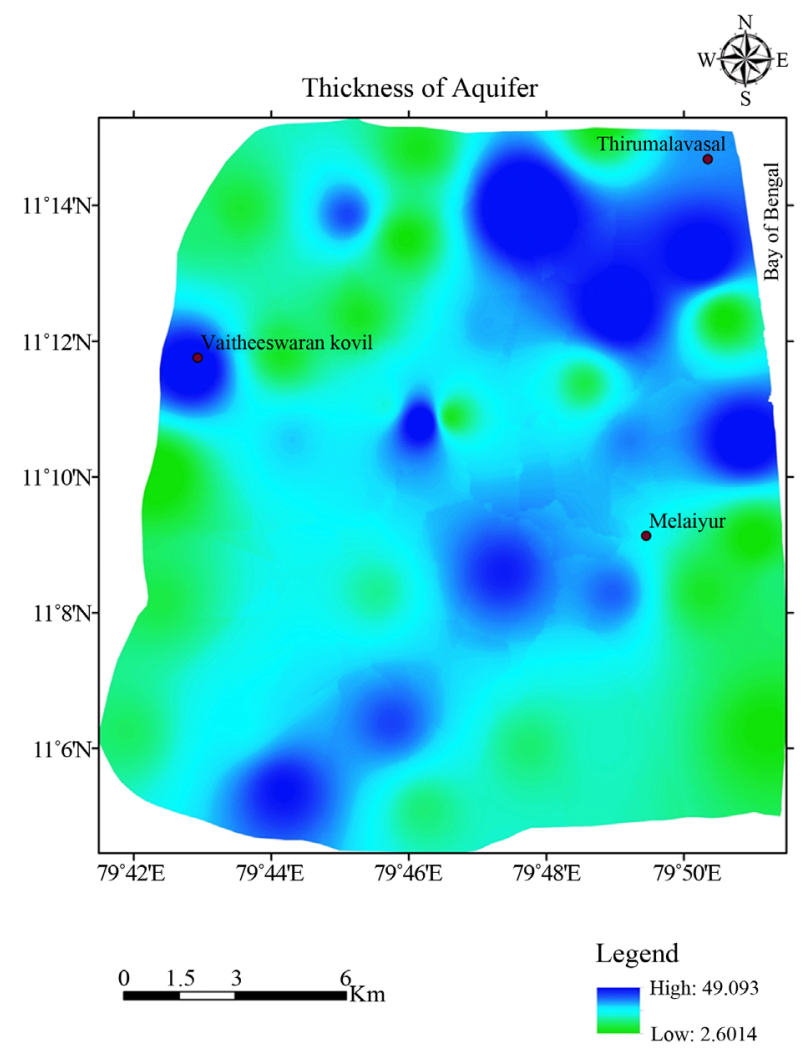

Figure 7. Parameter $Z$ (thickness of the aquifer).

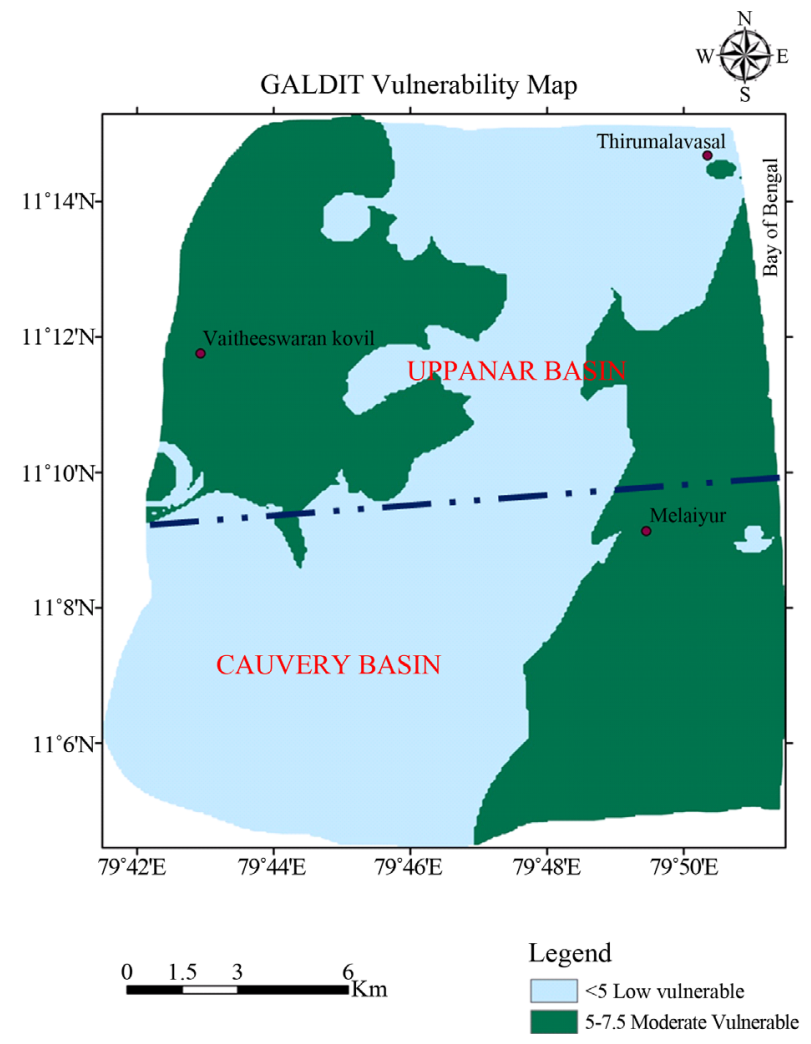

Figure 8. GALDID vulnerability model. 


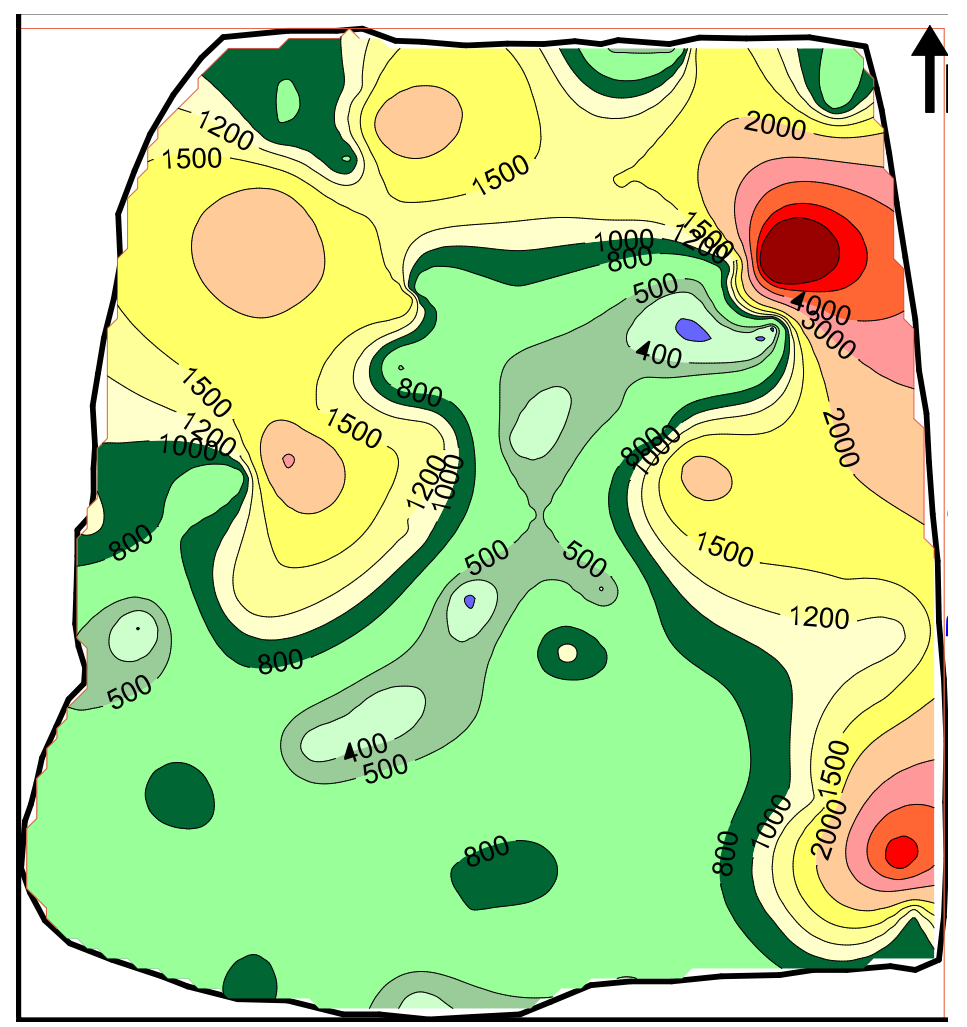

Figure 9. Total Dissolved Solids (TDS) values observed in Uppanar and Cauvery River Basin along cross sections.

(Cauvery formation) of the Cauvery River and its distributaries, fluviomarine deltaic plain deposits (Nagapattinam formation), marine coastal plain deposits (East Coast formation). Paleo-channels noticed with admixtures of sand, silt clay and gravels.

The application of GALDIT method to groundwater of Nagapattinam coast made it possible to evaluate the impact of the increase of saline level. The groundwater is characterized by a low vulnerability in the lower part of area i.e. Cauvery basin and a moderate vulnerability in upper part i.e. Uppanar basin with a strong contamination of the marine intrusion in the coast zone and in proximity of Uppanar River which is seen fresh from Figure 9. According to GALDIT method the aquifer is classified as moderate with an area of $147.31 \mathrm{sq} . \mathrm{km}$ and low covering an area of 168.72 sq. $\mathrm{km}$ in the entire coastal area taken into consideration.

\section{Acknowledgements}

The authors express their sincere gratitude to the Director, CSIR-NGRI, Hyderabad for his continuous support for the research activity.

\section{References}

[1] Todd, D.K. (1980) Ground Water Hydrology. John Wiley \& Sons, Singapore.

[2] White, I. and Falkland, T. (2010) Management of Freshwater Lenses on Small Pacific Islands. Hydrogeology Journal, 18, 227-246. http://dx.doi.org/10.1007/s10040-009-0525-0

[3] White, T., Falkland, T., Metutera, E., Metai, M., Overmars, P. and Perez, A. (2007) Dray Climatic and Human Influences on Groundwater in Low Atolls. Vadose Zone Journal, 6, 1-10. http://dx.doi.org/10.2136/vzj2006.0092

[4] Varnes, D.J. (1984) Landslides Hazard Zonation: A Review of Principles and Practice. UNESCO, Paris, 63 p.

[5] Georgescu, P., Dinu, C., Niculescu, V. and Ion, D. (1993) Some Applications of VES to Groundwater Exploration in 
the Vicinity of Romanian Coast of the Black Sea. Revue Roumaine de Geophysique, 37, 113-121.

[6] Lobo Ferreira, J.P. and Cabral, M. (1991) Proposal for an Operational Definition of Vulnerability from the European Community's Atlas of Groundwater Resources. In the Meeting of the European Institute for Water, Groundwater Work Group Brussels, February 1991.

[7] Chachadi, A.G., Lobo Ferreira, J.P., Noronha, L. and Choudri, B.S. (2002) Assessing the Impact of the Sea Level Rise on Saltwater Intrusion in Coastal Aquifers Using GALDIT Model. NIH, Roorkee, A Coastal Policy Research Newsletter, 7, 27-31.

[8] Cardona, A., Carrillo-Rivera, J., Huizar-Alvarez, R. and Gamiel, C.E. (2004) Salinization in Coastal Aquifers of Arid Zones: An Example from Santo Domingo, Baja California Sur, Mexico. Environmental Geology, 45, 350-366. http://dx.doi.org/10.1007/s00254-003-0874-2

[9] Lobo Ferreira, J.P. and Chachadi, A.G. (2005) Assessing Aquifer Vulnerability to Saltwater Intrusion Using GALDIT Method: Part 1-Application to the Portuguese Aquifer to Monte Gordo. Proceedings of 4th Interseltic Colloquim on Hydrology and Management of Water Resources, Portugal, 1-12.

[10] George, R.J., McFarlance, D.J. and Nulsen, R.A. (1997) Salinity Threatens the Viability of Agriculture and Ecosystems in Western Australia. Hydrogeology Journal, 5, 6-21. http://dx.doi.org/10.1007/s100400050103

[11] Kotb, T.H.S., Watanabe, T.Y., Ogino, Y. and Tanji, K.K. (2000) Soil Salinization in the Nile Delta and Related Policy Issues in Egypt. Agricultural Water Management, 43, 239-261. http://dx.doi.org/10.1016/S0378-3774(99)00052-9

[12] De Paz, J.M., Visconti, F., Zapata, R. and Sanchez, J. (2004) Integration of Two Simple Models in a Geographical Information System to Evaluate Salinization Risk in Irrigated Land of the Valencian Community, Spain. Soil Use and Management, 20, 333-342. http://dx.doi.org/10.1079/SUM2004265

[13] Asa Rani, L. and Suresh Babu, D.S. (2008) A Statistical Evaluation of Ground Water Chemistry for the West Coast of Tamil Nadu, India. Indian Journal of Geo-Marine Sciences, 37, 186-192.

[14] Zhang, X., Wang, Q., Liu, Y., Wu, J. and Yu, M. (2011) Application of Multivariate Statistical Techniques in the Assessment of Water Quality in the Southwest New Territories and Kowloon, Hong Kong. Environmental Monitoring and Assessment, 173, 17-27. http://dx.doi.org/10.1007/s10661-010-1366-y

[15] Ramakrishnan, M. (1988) Tectonic Evolution of the Archaean High Grade Terrain of South India. Journal of Geological Society of India, 32, 118-119.

[16] Central Ground Water Board (CGWB) (2008) District Groundwater Brochure Nagapattinam District, Tamil Nadu. CGWB Technical Report Series, South Eastern Coastal Region, Chennai, 1-15.

[17] Chachadi, A.G. and Lobo-Ferreira, J.P. (2001) Sea Water Intrusion Vulnerability Mapping of Aquifers Using GALDIT Method. Proceedings of the Workshop on Modelling in Hydrogeology, Anna University, Chennai, 143-156.

[18] Aller, L., Bennett, T., Lehr, J.H. and Petty, R.J. (1987) DRASTIC: A Standardized System for Evaluating Ground Water Pollution Potential Using Hydrogeologic Settings. US EPA Report 600/2-87/035.

[19] Chachadi, A.G., Lobo-Ferreira, J.P., Noronha, L. and Choudri, B.S. (2003) Assessing the Impact of Sea-Level Rise on Sea Water Intrusion in Coastal Aquifers Using GALDIT Model. APRH/CEAS, Seminário Sobre Águas Subterrâneas, Lisboa.

[20] Edet, A.E., Worden, R.H., Mohammed, E.A. and Preston, M.R. (2012) Hydrogeochemical Processes in a Shallow Coastal Plain Sand Aquifer and Tidal River Systems (Calabar, Southeastern Nigeria): Tracking Wastewater and Seawater Pollution in Ground and River Waters. Environmental Earth Sciences, 65, 1933-1953. http://dx.doi.org/10.1007/s12665-011-1175-9

[21] Chachadi, A.G. (2005) Seawater Intrusion Mapping Using Modified GALDIT Indicator Model-Case Study in Goa. Jalvigyan Sameeksha, 20.

[22] Revelle, R. (1941) Criteria for Recognition of Sea Water in Ground Waters. Eos, Transactions American Geophysical Union, 22, 593-597. http://dx.doi.org/10.1029/TR022i003p00593 


\section{Submit or recommend next manuscript to SCIRP and we will provide best service for you:}

Accepting pre-submission inquiries through Email, Facebook, LinkedIn, Twitter, etc.

A wide selection of journals (inclusive of 9 subjects, more than 200 journals)

Providing 24-hour high-quality service

User-friendly online submission system

Fair and swift peer-review system

Efficient typesetting and proofreading procedure

Display of the result of downloads and visits, as well as the number of cited articles

Maximum dissemination of your research work

Submit your manuscript at: http://papersubmission.scirp.org/ 